\title{
Desymmetrization of 7-azabicycloalkenes by tandem olefin metathesis for the preparation of natural product scaffolds
}

\author{
Wolfgang Maison ${ }^{*}$, Marina Büchert and Nina Deppermann
}

\section{Full Research Paper}

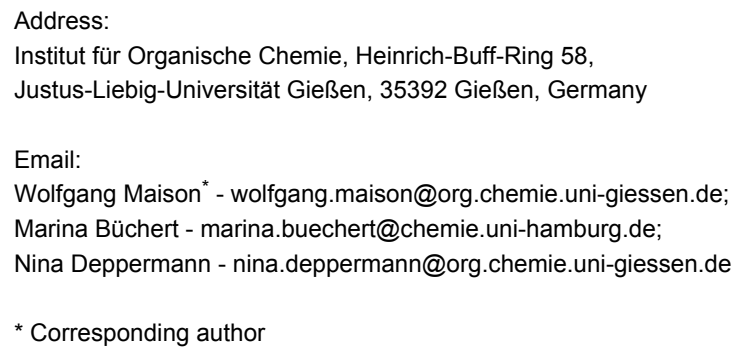

\section{Open Access}

Beilstein Journal of Organic Chemistry 2007, 3, No. 48 doi:10.1186/1860-5397-3-48

Received: 22 October 2007

Accepted: 18 December 2007

Published: 18 December 2007

(c) 2007 Maison et al; licensee Beilstein-Institut. License and terms: see end of document.

\section{Abstract}

\section{Background}

Tandem olefin metathesis sequences are known to be versatile for the generation of natural product scaffolds and have also been used for ring opening of strained carbo- and heterocycles. In this paper we demonstrate the potential of these reactions for the desymmetrization of 7-azabicycloalkenes.

\section{Results}

We have established efficient protocols for the desymmetrization of different 7-azabicycloalkenes by intra- and intermolecular tandem metathesis sequences with ruthenium based catalysts.

\section{Conclusion}

Desymmetrization of 7-azabicycloalkenes by olefin metathesis is an efficient process for the preparation of common natural product scaffolds such as pyrrolidines, indolizidines and isoindoles.

\section{Background}

Azabicyclo [x.y.0]alkane scaffolds are ubiquitous structural elements in pharmaceutically important peptide mimetics [1-3] and several important classes of natural products such as indolizidine and quinolizidine alkaloids and azasugars. [4-6] In consequence, a number of groups have developed efficient syntheses of these bicyclic heterocycles. [7-9] Challenges for the synthesis of these structures are the introduction of chirality and of several functional groups into the scaffolds. In particular the latter point is often a problem, leading to multistep sequences. 


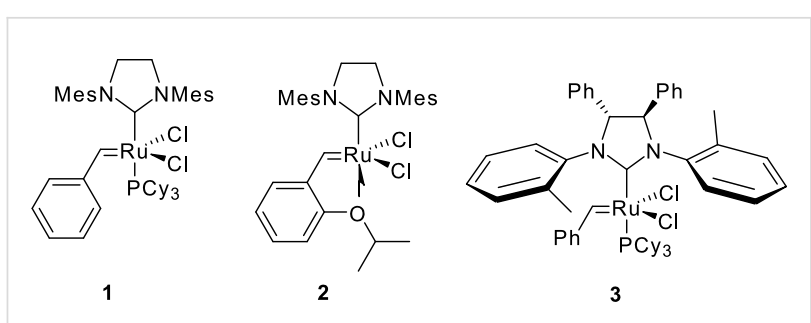

Figure 1: Ruthenium based precatalysts used in this study.

In this context, ring closing metathesis (RCM) and tandem metatheses [10-13] have been particularly successful strategies for the assembly of common natural product scaffolds. [14-22] A general advantage of these approaches is that ring closure and/or scaffold-rearrangements can be accomplished while generating a double bond as a valuable functional group for further manipulations. In addition, the common ruthenium (Figure 1) and molybdenum based catalysts for olefin metathesis are well known for their broad functional group tolerance.

The application of RCM to the synthesis of azabicycloalkane scaffolds was first described by Grubbs[23] for the synthesis of peptide mimetics and later extended by several other groups. [24-31] Key intermediates in these approaches are often alkenyl substituted pyrrolidines, which are $N$-acylated with an unsaturated carboxylic acid and submitted to a ring closing metathesis (RCM).

As a part of a general synthetic concept using azabicycloalkenes as masked analogs of functionalized pyrrolidines or piperidines [32-39] we have previously applied the concept of intramolecular ring-opening/ring-closing metathesis (RORCM) [40-54] to $N$-acylated 2-azabicycloalkenes 4 as precursors for azabicyclo [X.3.0]alkanes like 6 (Scheme 1).[55] Various other strained heterocycles have also been used for ring opening metathesis or other tandem metathesis sequences. [56-61]

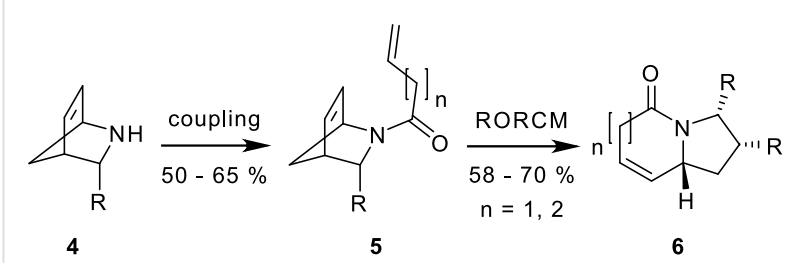

Scheme 1: RORCM of 2-azabicycloalkenes 5 to bicyclic scaffolds 6 .

In this paper, we describe the extension of this work and show that desymmetrization of 7-azabicycloalkenes via RORCM leads to valuable natural product scaffolds. In this context, symmetrical derivatives of 7-azabicycloalkenes like $\mathbf{7}$ and $\mathbf{1 2}$ are extremely interesting substrates for RORCM conversions, because they may be desymmetrized either by diastereoselective or enantioselective metathesis.

\section{Results and Discussion}

In a first attempt to transfer the RORCM-strategy to 7-azabicycloalkenes, we chose 7 as a precursor for domino metathesis reactions. Our choice was due to the following two reasons: 1. Azabicycloalkene 7 is easy to synthesize via Diels-Alder reaction.[62] 2. It was assumed to be a good substrate for RORCM because it is strained and has been shown to be susceptible to other desymmetrizing ring opening reactions in the past.[63,64]

To generate appropriate precursors for the tandem conversions, 7 was deprotected and acylated with butenoic acid and pentenoyl chloride to give $\mathbf{8}$ and $\mathbf{1 0}$. However, first attempts to convert the bis-olefin 8 via RORCM to the bicyclic target structure failed and only pyridone derivative 9 was isolated in small quantities along with large amounts of unreacted starting material. With turnover numbers of only three, the ruthenium based catalysts $\mathbf{1}$ and $\mathbf{2}$ were both quite ineffective in this metathesis reaction.

We assumed that the structure of the starting material 8 (location of the exocyclic double bond) and the following aromatization to 9 was the reason for the low catalytic efficiency of this conversion and tested this hypothesis with the conversion of the corresponding pentenoyl derivative 10 under RORCM conditions. As outline in Scheme 2, this reaction gave the expected metathesis product, which was hydrogenated to the isoindole derivative $\mathbf{1 1}$ in good yield, verifying our previous assumptions.

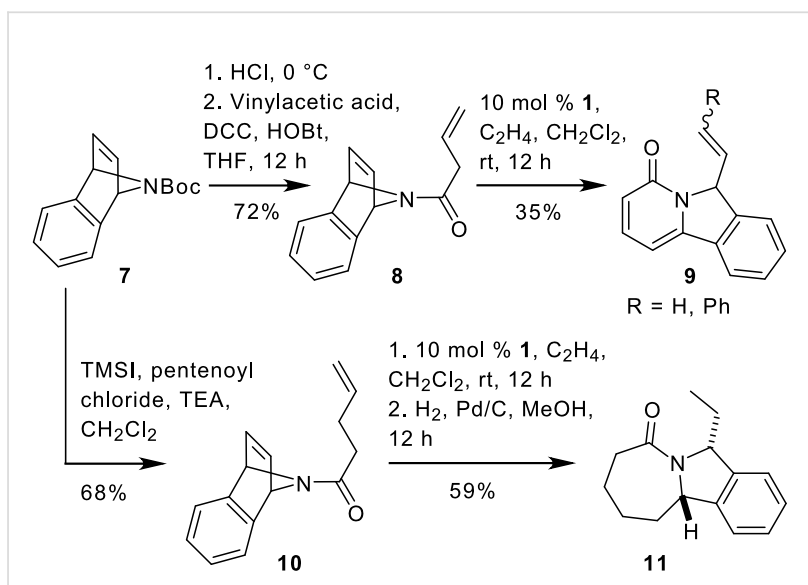

Scheme 2: RORCM of 7-azabicycloalkenes $\mathbf{8}$ and $\mathbf{1 0}$ to pyridone $\mathbf{9}$ and isoindole scaffold 11.

As a general trend, it turned out that benzannelated azabicycloalkene derivatives like $\mathbf{8}$ and $\mathbf{1 0}$ give relatively unstable products. In consequence, products can only be isolated as 


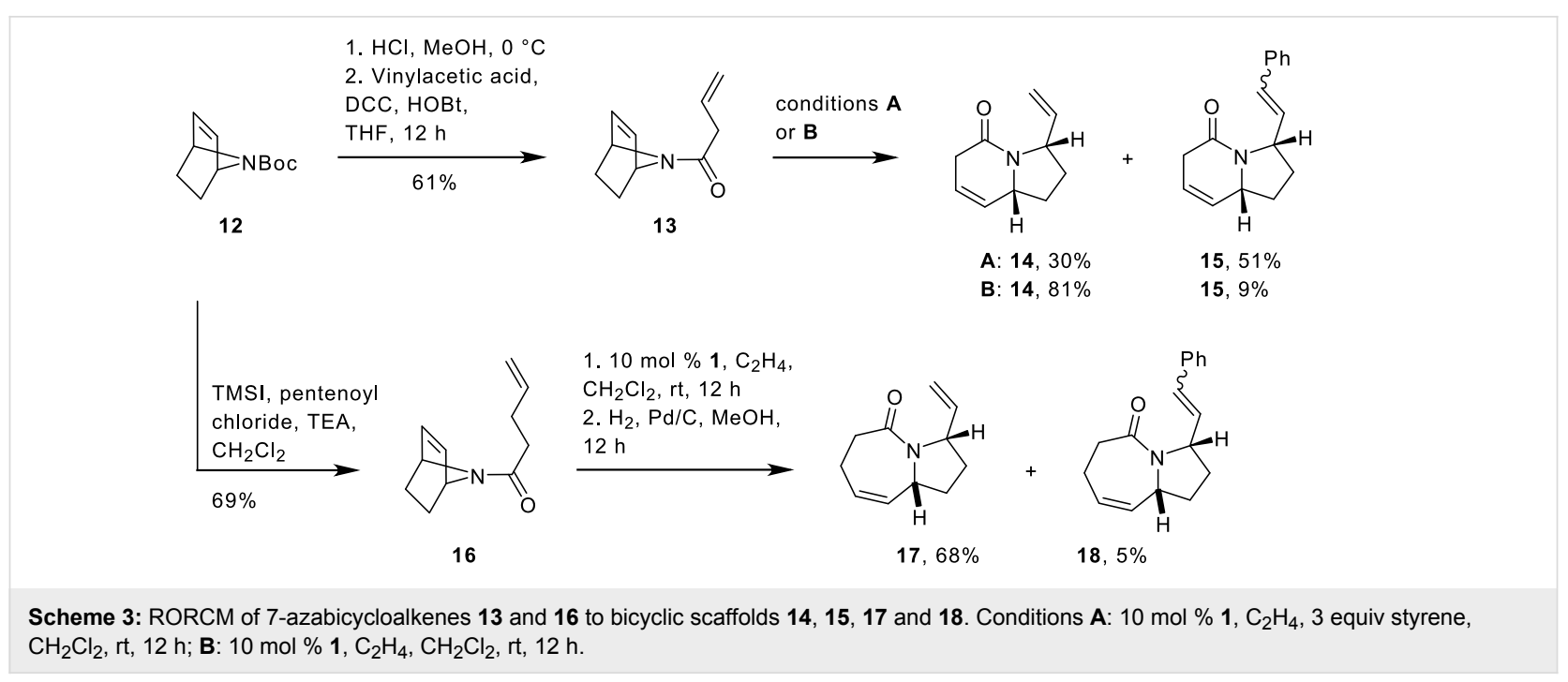

pyridones $\mathbf{9}$, derived from spontaneous aromatization or have to be hydrogenated to their saturated analogues $\mathbf{1 1}$.

This unique reactivity of benzannelated metathesis precursors like $\mathbf{8}$ and $\mathbf{1 0}$ is not observed with other 7-azabicycloalkenes like $\mathbf{1 3}$ and $\mathbf{1 6}$ as depicted in Scheme 3. Starting from the known Boc-protected heterocycle 12,[65,66] RORCM precursors $\mathbf{1 3}$ and $\mathbf{1 6}$ were generated after deprotection under standard acylation conditions in good yields. Treatment of these bis-olefins with Grubbs catalyst 1 gave the expected bicyclic compounds $\mathbf{1 4}$ and $\mathbf{1 7}$ in good yield along with some byproducts 15 and 18 , respectively. These byproducts are often observed, if the generated exocyclic double bond in the RORCM product is susceptible to olefin cross metathesis with the small amount of styrene that is derived from the precatalyst 1. These types of products are favored, if additional olefins are added as CM partners. With addition of 3 equivalents styrene (condition $\mathbf{A}$ in Scheme 3), for example, the styrene adduct 15 becomes the main product.

Having established suitable protocols for conversions of 7 -azabicycloalkenes to racemic products, we tried next to develop stereoselective variants and started our studies again with Boc-protected 7-azabicycloalkenes 7 and 12. A sequence of ring opening and cross metathesis is extremely efficient for desymmetrization of $\mathbf{7}$ and $\mathbf{1 2}$ as depicted in Scheme 4 for the synthesis of isoindole 19 and the disubstituted pyrrolidine 20. In these cases, catalyst loadings can be low and yields are excellent.

Unfortunately the ROCM of 7-azabicycloalkenes appeared to be quite sensitive with respect to the olefin cross metathesis partner [67] and we have not been able to transfer this reaction to $\alpha$-substituted olefins like 21 yet.

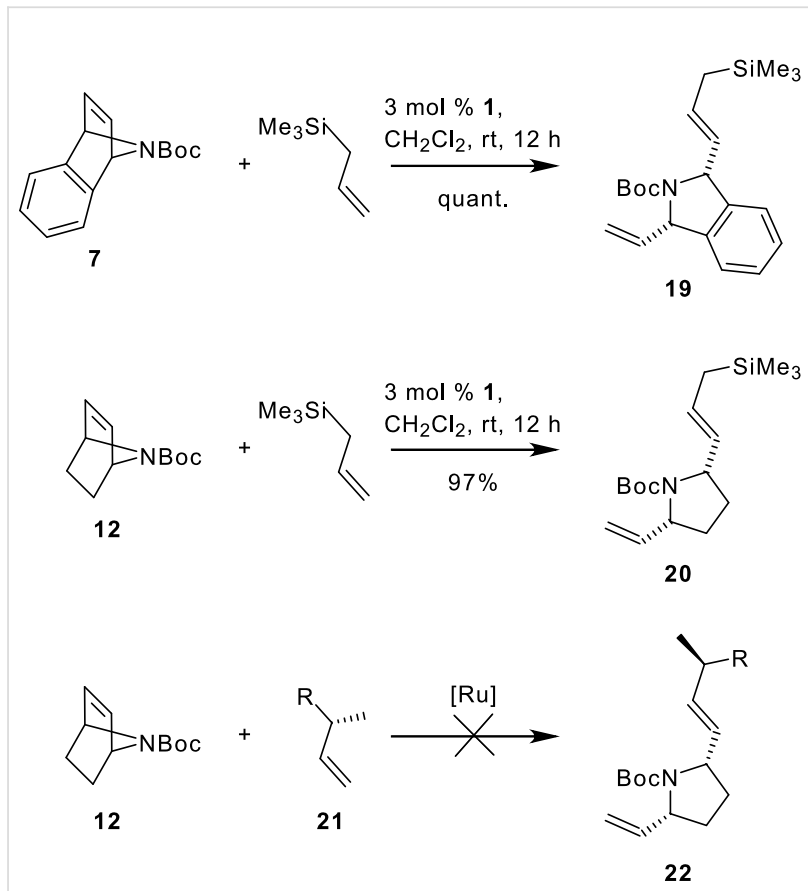

Scheme 4: ROCM of 7-azabicycloalkenes 7 and 12 to isoindole and pyrrolidine scaffolds 19 and 20.

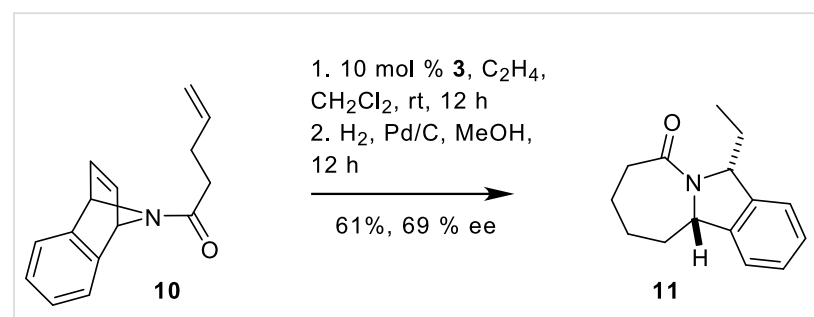

Scheme 5: Catalytic enantioselective desymmetrization of 7-azabicycloalkene 10 to scaffold 23. 
A more successful attempt to introduce selectivity, was the enantioselective catalytic desymmetrization of bis-olefin $\mathbf{1 0}$ with the known chiral ruthenium catalyst 3.[67] This reaction gave enantioenriched $\mathbf{1 1}$ in good yield (Scheme 5). However, the enantioselectivity of this reaction is only moderate compared to similar reactions using molybdenum based precatalysts and different azabicycloalkene starting materials that have been recently reported by Hoveyda and Schrock for the enantioselective preparation of piperidines. $[68,69]$

\section{Conclusion}

In this paper we have described efficient tandem metathesis protocols for the desymmetrization of 7-azabicycloalkenes. Desymmetrization is accomplished by intramolecular RORCM or intermolecular ROCM sequences to give a range of common natural product scaffolds such as pyrrolidines, indolizidines and isoindoles. The protocols use readily available starting materials, are simple and give densely functionalized metathesis products ready for further manipulations.

\section{Supporting Information}

\section{Supporting Information File 1}

Experimental. Experimental procedures for the synthesis of all compounds described, and characterization data for the synthesized compounds.

[http://www.beilstein-journals.org/bjoc/content/ supplementary/1860-5397-3-48-S1.doc]

\section{Acknowledgments}

We gratefully acknowledge support from the Deutsche Forschungsgemeinschaft (DFG, MA 2529/1) and from the Fonds der Chemischen Industrie.

\section{References}

1. Cluzeau, J.; Lubell, W. D. Biopolymers 2005, 80, 98-150. doi:10.1002/bip.20213

2. Belvisi, L.; Colombo, L.; Manzoni, L.; Potenza, D.; Scolastico, C. Synlett 2004, 1449-1471. doi:10.1055/s-2004-829540

3. Suat Kee, K.; Jois, S. D. S. Curr. Pharm. Des. 2003, 9, 1209-1224. doi:10.2174/1381612033454900

4. Michael, J. P. Nat. Prod. Rep. 2007, 24, 191-222. doi:10.1039/b509525p And previous articles of this series.

5. Felpin, F. X.; Lebreton, J. Eur. J. Org. Chem. 2003, 3693-3712. doi:10.1002/ejoc.200300193

6. Yoda, H. Curr. Org. Chem. 2002, 6, 223-243. doi:10.2174/1385272024605069

7. Maison, W.; Prenzel, A. H. G. P. Synthesis 2005, 1031-1049. doi:10.1055/s-2005-865295

8. Enders, D.; Thiebes, T. Pure Appl. Chem. 2001, 73, 573-578. doi:10.1351/pac200173030573
9. Hanessian, S.; McNaughton-Smith, G.; Lombart, H. G.; Lubell, W. D. Tetrahedron 1997, 53, 12789-12854. doi:10.1016/S0040-4020(97)00298-6

10. Astruc, D. New J. Chem. 2005, 29, 42-56. doi:10.1039/b412198h

11. Grubbs, R. H. Tetrahedron 2004, 60, 7117-7140. doi:10.1016/j.tet.2004.05.124

12. Schrock, R. R.; Hoveyda, A. H. Angew. Chem., Int. Ed. 2003, 42, 4592-4633. doi:10.1002/anie.200300576

13. Fuerstner, A. Angew. Chem., Int. Ed. 2000, 39, 3012-3043. doi:10.1002/1521-3773(20000901)39:17<3012::AID-ANIE3012>3.0.CO ;2-G

14. Martin, W. H. C.; Blechert, S. Curr. Top. Med. Chem. 2005, 5, 1521-1540. doi:10.2174/156802605775009757

15. Nakamura, I.; Yamamoto, Y. Chem. Rev. 2004, 104, 2127-2198. doi:10.1021/cr020095i

16. Deiters, A.; Martin, S. F. Chem. Rev. 2004, 104, 2199-2238. doi:10.1021/cr0200872

17. Larry, Y. Chem. Rev. 2000, 100, 2963-3008. doi:10.1021/cr990407q

18. Phillips, A. J.; Abell, A. D. Aldrichimica Acta 1999, 32, 75-89.

19. Fuerstner, A. Top. Organomet. Chem. 1998, 1, 37-72.

20. Armstrong, S. J. Chem. Soc., Perkin Trans. 11998, 371-388. doi:10.1039/a703881j

21. Grubbs, R. H. Tetrahedron 1998, 54, 4413-4450. doi:10.1016/S0040-4020(97)10427-6

22. Schuster, M.; Blechert, S. Angew. Chem., Int. Ed. Engl. 1997, 36, 2037-2056. doi:10.1002/anie.199720361

23. Miller, S. J.; Grubbs, R. H. J. Am. Chem. Soc. 1995, 117, 5855-5856. doi:10.1021/ja00126a027

24. Manzoni, L.; Colombo, M.; Scolastico, C. Tetrahedron Lett. 2004, 45, 2623-2625. doi:10.1016/j.tetlet.2004.01.126

25. Krelaus, R.; Westermann, B. Tetrahedron Lett. 2004, 45, 5987-5990. doi:10.1016/j.tetlet.2004.06.052

26. Harris, P. W. R.; Brimble, M. A.; Gluckman, P. D. Org. Lett. 2003, 5, 1847-1850. doi:10.1021/ol034370e

27. Hoffmann, T.; Lanig, H.; Waibel, R.; Gmeiner, P. Angew. Chem., Int. Ed. 2001, 40, 3361-3364. doi:10.1002/1521-3773(20010917)40:18<3361::AID-ANIE3361>3.0.CO ;2-9

28. Lim, S. H.; Ma, S.; Beak, P. J. Org. Chem. 2001, 66, 9056-9062. doi:10.1021/jo0108865

29. Beal, L. M.; Liu, B.; Chu, W.; Moeller, K. D. Tetrahedron 2000, 56, 10113-10125. doi:10.1016/S0040-4020(00)00856-5

30. Grossmith, C. E.; Senia, F.; Wagner, J. Synlett 1999, 1660-1662. doi:10.1055/s-1999-2887

31. Beal, L. M.; Moeller, K. D. Tetrahedron Lett. 1998, 39, 4639-4642. doi:10.1016/S0040-4039(98)00858-2

32. Grohs, D. C.; Maison, W. Amino Acids 2005, 29, 131-138. doi:10.1007/s00726-005-0182-0

33. Grohs, D. C.; Maison, W. Tetrahedron Lett. 2005, 46, 4373-4376. doi:10.1016/j.tetlet.2005.04.082

34. Maison, W.; Grohs, D. C.; Prenzel, A. H. G. P. Eur. J. Org. Chem. 2004, 1527-1543. doi:10.1002/ejoc.200300700

35. Arakawa, Y.; Ohnishi, M.; Yoshimura, N.; Yoshifuji, S. Chem. Pharm. Bull. 2003, 51, 1015-1020. doi:10.1248/cpb.51.1015

36. Arakawa, Y.; Murakami, T.; Yoshifuji, S. Chem. Pharm. Bull. 2003, 51, 96-97. doi:10.1248/cpb.51.96

37. Arakawa, Y.; Murakami, T.; Ozawa, F.; Arakawa, Y.; Yoshifuji, S. Tetrahedron 2003, 59, 7555-7563. doi:10.1016/S0040-4020(03)01200-6 
38. Maison, W.; Küntzer, D.; Grohs, D. C. Synlett 2002, 1795-1798. doi:10.1055/s-2002-34901

39. Jaeger, M.; Polborn, K.; Steglich, W. Tetrahedron Lett. 1995, 36, 861-864. doi:10.1016/0040-4039(94)02432-B

40. Hart, A. C.; Phillips, A. J. J. Am. Chem. Soc. 2006, 128, 1094-1095. doi:10.1021/ja057899a

41. Funel, J. A.; Prunet, J. Synlett 2005, 235-238. doi:10.1055/s-2004-837200

42. Takao, K. I.; Yasui, H.; Yamamoto, S.; Sasaki, D.; Kawasaki, S.; Watanabe, G.; Tadano, K. I. J. Org. Chem. 2004, 69, 8789-8795. doi:10.1021/jo048566j

43. Lesma, G.; Crippa, S.; Danieli, B.; Sacchetti, A.; Silvani, A.; Virdis, A. Tetrahedron 2004, 60, 6437-6442. doi:10.1016/j.tet.2004.06.051

44. Holtsclaw, J.; Koreeda, M. Org. Lett. 2004, 6, 3719-3722. doi:10.1021/ol048650l

45. Schaudt, M.; Blechert, S. J. Org. Chem. 2003, 68, 2913-2920. doi:10.1021/j0026803h

46. Wrobleski, A.; Sahasrabudhe, K.; Aubé, J. J. Am. Chem. Soc. 2002, 124, 9974-9975. doi:10.1021/ja027113y

47. Hagiwara, H.; Katsumi, T.; Endou, S.; Hoshi, T.; Suzuki, T. Tetrahedron 2002, 58, 6651-6654. doi:10.1016/S0040-4020(02)00690-7

48. Banti, D.; North, M. Tetrahedron Lett. 2002, 43, 1561-1564. doi:10.1016/S0040-4039(02)00009-6

49. Minger, T. L.; Phillips, A. J. Tetrahedron Lett. 2002, 43, 5357-5359. doi:10.1016/S0040-4039(02)00905-X

50. Limanto, J.; Snapper, M. L. J. Am. Chem. Soc. 2000, 122, 8071-8072. doi:10.1021/ja001946b

51. Adams, J. A.; Ford, J. G.; Stamatos, P. J.; Hoveyda, A. H. J. Org. Chem. 1999, 64, 9690-9696. doi:10.1021/jo991323k

52. Stragies, R.; Blechert, S. Synlett 1998, 169-170. doi:10.1055/s-1998-1592

53. Burke, S. D.; Quinn, K. J.; Chen, V. J. J. Org. Chem. 1998, 63 , 8626-8627. doi:10.1021/jo981342e

54. Stille, J. R.; Santarsiero, B. D.; Grubbs, R. H. J. Org. Chem. 1990, 55, 843-862. doi:10.1021/jo00290a013

55. Büchert, M.; Meinke, S.; Prenzel, A. H. G. P.; Deppermann, N.; Maison, W. Org. Lett. 2006, 8, 5553-5556. doi:10.1021/ol062219+ For a parallel study in the Blechert group see: N. Rodriguez y Fischer, Ringumlagerungsmetathesen zu Azacyclen, Dissertation, TU Berlin, 2004.

56. Dunne, A. M.; Mix, S.; Blechert, S. Tetrahedron Lett. 2003, 44, 2733-2736. doi:10.1016/S0040-4039(03)00346-0

57. Arjona, O.; Csáky, A. G.; Medel, R.; Plumet, J. J. Org. Chem. 2002, 67, 1380-1383. doi:10.1021/jo016000e

58. Ishikura, M.; Saijo, M.; Hino, A. Heterocycles 2003, 59, 573-585.

59. Arjona, O.; Csák, A. G.; Plumet, J. Eur. J. Org. Chem. 2003, 611-622. doi:10.1002/ejoc.200390100

60. Liu, Z.; Rainier, J. D. Org. Lett. 2006, 8, 459-462. doi:10.1021/ol052741g

61. Liu, Z.; Rainier, J. D. Org. Lett. 2005, 7, 131-133. doi:10.1021/ol047808z

62. Lautens, M.; Fagnou, K.; Zunic, V. Org. Lett. 2002, 4, 3465-3468. doi:10.1021/ol026579i

63. Cho, Y. H.; Zunic, V.; Senboku, H.; Olsen, M.; Lautens, M. J. Am. Chem. Soc. 2006, 128, 6837-6846. doi:10.1021/ja0577701 And references cited therein.

64. Namyslo, J. C.; Kaufmann, D. E. Synlett 1999, 804-806. doi:10.1055/s-1999-2719
65. Liang, F.; Navarro, H. A.; Abraham, P.; Kotian, P.; Ding, Y. S.; Fowler, J.; Volkow, N.; Kuhar, M. J.; Carroll, F. I. J. Med. Chem. 1997, 40, 2293-2295. doi:10.1021/jm970187d

66. Chatterjee, A. K.; Choi, T. L.; Sanders, D. P.; Grubbs, R. H. J. Am. Chem. Soc. 2003, 125, 11360-11370. doi:10.1021/ja0214882

67. Seiders, T. J.; Ward, D. W.; Grubbs, R. H. Org. Lett. 2001, 3, 3225-3228. doi:10.1021/ol0165692

68. Cortez, G. A.; Baxter, C. A.; Schrock, R. R.; Hoveyda, A. H. Org. Lett. 2007, 9, 2871-2874. doi:10.1021/ol071008h

69. Cortez, G. A.; Schrock, R. R.; Hoveyda, A. H. Angew. Chem., Int. Ed. 2007, 46, 4534-4538. doi:10.1002/anie.200605130

\section{License and Terms}

This is an Open Access article under the terms of the Creative Commons Attribution License

(http://creativecommons.org/licenses/by/2.0), which permits unrestricted use, distribution, and reproduction in any medium, provided the original work is properly cited.

The license is subject to the Beilstein Journal of Organic Chemistry terms and conditions: (http://www.beilstein-journals.org/bjoc)

The definitive version of this article is the electronic one which can be found at: doi:10.1186/1860-5397-3-48 